\title{
Synergy and Anti-Synergy between Palladium and Gold in Nanoparticles Dispersed on a Reducible Support
}

\author{
James H. Carter, ${ }^{\dagger}$ Sultan Althahban, ${ }^{\ddagger}$ Ewa Nowicka, ${ }^{\dagger}$ Simon J. Freakley, ${ }^{\dagger}$ David J. Morgan, ${ }^{\dagger}$ \\ Parag M. Shah, ${ }^{\dagger}$ Stanislaw Golunski, ${ }^{\dagger}$ Christopher J. Kiely, ${ }^{\ddagger}$ and Graham J. Hutchings ${ }^{*}{ }^{\dagger}$ \\ ${ }^{\dagger}$ Cardiff Catalysis Institute, School of Chemistry, Cardiff University, Main Building, Park Place, Cardiff CF10 3AT, U.K. \\ ${ }^{*}$ Department of Materials Science and Engineering, Lehigh University, 5 East Packer Avenue, Bethlehem, Pennsylvania 18015-3195, \\ United States
}

\section{Supporting Information}

ABSTRACT: Highly active and stable bimetallic $\mathrm{Au}-\mathrm{Pd}$ catalysts have been extensively studied for several liquid-phase oxidation reactions in recent years, but there are far fewer reports on the use of these catalysts for low-temperature gasphase reactions. Here we initially established the presence of a synergistic effect in a range of bimetallic $\mathrm{Au}-\mathrm{Pd} / \mathrm{CeZrO}_{4}$ catalysts, by measuring their activity for selective oxidation of benzyl alcohol. The catalysts were then evaluated for lowtemperature WGS, CO oxidation, and formic acid decomposition, all of which are believed to be mechanistically related. A strong anti-synergy between $\mathrm{Au}$ and Pd was observed for these reactions, whereby the introduction of $\mathrm{Pd}$ to a monometallic $\mathrm{Au}$ catalyst resulted in a significant decrease in catalytic activity. Furthermore, monometallic Pd was more active than Pd-rich bimetallic catalysts. The nature of the anti-synergy was probed by several ex situ techniques, which all indicated a growth in metal nanoparticle size with Pd addition. However, the most definitive information was provided by in situ CO-DRIFTS, in which CO adsorption associated with interfacial sites was found to vary with the molar ratio of the metals and could be correlated with the catalytic activity of each reaction. As a similar correlation was observed between activity and the presence of $\mathrm{Au}^{0 *}$ (as detected by XPS), it is proposed that peripheral $\mathrm{Au}^{0 *}$ species form part of the active centers in the most active catalysts for the three gasphase reactions. In contrast, the active sites for the selective oxidation of benzyl alcohol are generally thought to be electronically modified gold atoms at the surface of the nanoparticles.

KEYWORDS: water-gas shift, CO oxidation, formic acid, gold, palladium, gold-palladium alloy, ceria-zirconia

\section{INTRODUCTION}

Since the early reports of the high activity of gold as a catalyst for the hydrochlorination of acetylene ${ }^{1}$ and low-temperature $\mathrm{CO}$ oxidation, ${ }^{2}$ this precious metal has been shown to catalyze a wide range of reactions, including the low-temperature watergas shift (WGS) reaction, ${ }^{3}$ the selective hydrogenation of nitro arenes, ${ }^{4}$ and the upgrading of hydrocarbons. ${ }^{5}$ The addition of $\mathrm{Pd}$ to $\mathrm{Au}$ has been shown to yield materials that are significantly more reactive and stable than their equivalent monometallic catalysts. This synergistic effect has been observed in several systems, including the direct synthesis of hydrogen peroxide, ${ }^{6}$ benzyl alcohol oxidation, ${ }^{7}$ glycerol oxidation, ${ }^{8}$ and vinyl acetate synthesis. ${ }^{9}$ For CO oxidation and low-temperature WGS there are few publications relating to supported $\mathrm{Au}-\mathrm{Pd}$ systems, which is surprising given their successful application in other oxidation reactions.

There has been a renewed interest in the low-temperature WGS reaction because of its potential application in $\mathrm{CO}$ removal from reformate in the context of fuel cell technology.
Conventional WGS catalysts based on $\mathrm{Cu} / \mathrm{ZnO}$ systems are not intrinsically active enough, require prereduction steps, and are pyrophoric once activated. Alternative noncopper catalysts are being developed, most notably by Hardacre and co-workers, who discovered the remarkable activity of $\mathrm{Au}$ supported on $\mathrm{CeZrO}_{4}{ }^{10}$ However, rapid deactivation of this catalyst was observed under reaction conditions ${ }^{11}$ and, although $\mathrm{Au}$ dispersed on ceria-based supports have been widely investigated, ${ }^{12-19}$ very few Au-containing bimetallic catalysts have been considered as candidates for this reaction.

The sparse experimental reports of $\mathrm{Au}-\mathrm{Pd}$ catalysts for $\mathrm{CO}$ oxidation have often focused on nonreducible supports such as $\mathrm{SiO}_{2},{ }^{20,21}$ which consequently makes direct comparisons with reducible supports such as $\mathrm{CeZrO}_{4}$ difficult, as it has been shown that the support identity is a critical parameter in

Received: May 6, 2016

Revised: August 3, 2016

Published: August 29, 2016 
catalytic activity for $\mathrm{CO}$ oxidation. ${ }^{22,23}$ However, Chen and coworkers recently screened bimetallic $\mathrm{Au}-\mathrm{Pd} / \mathrm{Ce}_{0.62} \mathrm{Zr}_{0.38} \mathrm{O}_{2}$ catalysts for $\mathrm{CO}$ oxidation and showed that the addition of Pd leads to a decrease in the catalytic activity as a result of partial active site blocking. ${ }^{24}$ Venezia et al. studied a range of $\mathrm{SiO}_{2}$ supported $\mathrm{Au}-\mathrm{Pd}$ catalysts and found that, for a nonreducible support such as $\mathrm{SiO}_{2}$, pure $\mathrm{Pd}$ gives the most active catalyst. ${ }^{25}$ The authors attributed the inactivity of Aucontaining catalysts to the larger size of $\mathrm{Au}$ nanoparticles in comparison to $\mathrm{Pd}$, although the ability of $\mathrm{Pd}$ to activate $\mathrm{O}_{2}$ should also be considered significant. As $\mathrm{O}_{2}$ activation does not occur on pure $\mathrm{Au}$, it is unsurprising that it is inactive for $\mathrm{CO}$ oxidation, a finding also reported by Huang and co-workers. ${ }^{21}$ For $\mathrm{TiO}_{2}$-supported $\mathrm{Au}-\mathrm{Pd}$ catalysts, Beck et al. used a selection of preparation methods to achieve different nanostructured bimetallic catalysts. No significant synergy was observed in those catalysts, regardless of the preparation method, indicating that the presence of core-shell structures does not adversely or positively affect the catalytic activity for $\mathrm{CO}$ oxidation. ${ }^{26}$ One possible explanation of this effect is the segregation of $\mathrm{Au}$ and $\mathrm{Pd}$ alloys that has been noted in $\mathrm{Au}-\mathrm{Pd}$ alloys under various atmospheres, especially under $\mathrm{CO}$ exposure, whereby the strong affinity of $\mathrm{CO}$ for $\mathrm{Pd}$ causes it to preferentially migrate to the surface. ${ }^{27}$

However, this structure insensitivity was also investigated by Lopez-Sanchez et al. using $\mathrm{Au}-\mathrm{Pd} / \mathrm{TiO}_{2}$ materials prepared by colloidal methods. They studied $\mathrm{CO}$ oxidation and concluded that the introduction of $\mathrm{Pd}$ to $\mathrm{Au}$ was not beneficial for the catalysis but did not explain the underlying reasons for the observation. $^{28}$ Recently, a number of theoretical and model catalyst studies ${ }^{28-30}$ have predicted that $\mathrm{Au}-\mathrm{Pd}$ alloy catalysts should be active for $\mathrm{CO}$ oxidation. In a density functional theory study, $\mathrm{Ham}$ et al. attempted to rationalize $\mathrm{Au}-\mathrm{Pd}$ interactions with $\mathrm{CO}$ and $\mathrm{O}_{2}$ on $\mathrm{Au}-\mathrm{Pd}(111)$ surfaces. Their calculations predicted that "partially-poisoned" $\mathrm{Pd}$ ensembles would facilitate the activation of $\mathrm{O}_{2}$ and subsequent reaction with $\mathrm{CO}$, making $\mathrm{Au}-\mathrm{Pd}$ alloys potentially highly active for $\mathrm{CO}$ oxidation. ${ }^{29}$ The importance of $\mathrm{Pd}$ in dissociating $\mathrm{O}_{2}$ has also been reported by Gao et al. in an investigation of model $\mathrm{Au}-$ $\operatorname{Pd}(100)$ surfaces. ${ }^{30}$ Saqlain et al. conducted a DFT study which predicted that $\mathrm{Au}$ and Pd should be highly active for the WGS reaction, due to the low energy barriers associated with $\mathrm{H}_{2} \mathrm{O}$ dissociation and $\mathrm{CO}$ oxidation, ${ }^{31}$ but there have been no reported experimental studies to confirm this.

Bond recently examined the mechanisms of the WGS reaction, citing the carboxyl mechanism as a promising candidate. ${ }^{32}$ In doing so, he also identified similarities with formic acid decomposition (FAD), which proceeds through the same intermediate and is catalyzed by similar gold-supported systems. Bond suggested that FAD could be a useful test reaction for WGS catalysts, and he also proposed that gold alloys such as $\mathrm{Au}-\mathrm{Pd}$ should be investigated, given their successful application in similar areas.

Overall there is a body of literature that predicts $\mathrm{Au}-\mathrm{Pd}$ catalysts to be highly active for WGS, FAD, and CO oxidation, but this has not been matched or verified by the existing experimental reports. The current work aims at investigating the effect of introducing $\mathrm{Pd}$ into a highly active $\mathrm{Au} / \mathrm{CeZ} \mathrm{rO}_{4}$ catalyst for these reactions and to compare their catalytic activity. As it is well documented that $\mathrm{Au}-\mathrm{Pd}$ catalysts display synergy for the selective oxidation of benzyl alcohol, ${ }^{33-38}$ a selection of $\mathrm{Au}-\mathrm{Pd} / \mathrm{CeZrO}_{4}$ catalysts was screened for this reaction to confirm the presence of the synergistic effect, before proceeding to the WGS, $\mathrm{CO}$ oxidation, and $\mathrm{FAD}$ studies.

\section{EXPERIMENTAL SECTION}

All catalysts were prepared by a deposition-precipitation (DP) method. Aqueous solutions of $\mathrm{HAuCl}_{4}(0.067 \mathrm{M})$ and $\mathrm{PdCl}_{2}$ $(0.072 \mathrm{M})$ were used as the metal precursors. Ceria-zirconia (supplied by Solvay as $\mathrm{CeZrO}_{4}$ ) was used as the support. Typically, deionized water $\left(200 \mathrm{~cm}^{3}\right)$ was stirred at $60{ }^{\circ} \mathrm{C}$ before the addition of the appropriate metal precursor(s) to give total target metal loadings of 2 wt \%. The appropriate quantity of support was added to the solution for $15 \mathrm{~min}$ before the dropwise addition of $\mathrm{Na}_{2} \mathrm{CO}_{3}(0.05 \mathrm{M})$ to increase the $\mathrm{pH}$ to 8 . The reaction mixture was then stirred for $1 \mathrm{~h}$ before being filtered and washed with deionized water $\left(800 \mathrm{~cm}^{3}\right)$. The catalysts were then dried at $110{ }^{\circ} \mathrm{C}$ for $5 \mathrm{~h}$.

The metal loadings of the catalysts were determined using an Agilent 4100 MP-AES spectrometer equipped with a nitrogen plasma. A sample of each catalyst $(50 \mathrm{mg})$ was digested in aqua regia $\left(4 \mathrm{~cm}^{3}\right)$ at ambient temperature for $16 \mathrm{~h}$, before dilution in deionized water up to a total volume of $50 \mathrm{~cm}^{3}$. Any remaining solids were filtered before analyzing the final solution. The measured precious-metal loadings of each catalyst were invariably lower than the theoretical nominal values, which is typical for highly dispersed nanoparticle catalysts prepared by deposition-precipitation. The catalysts are denoted in the Results and Discussion and figures as $\mathrm{Au}_{x} \mathrm{Pd}_{y} /$ $\mathrm{CeZrO}_{4}$, where $x$ and $y$ are the molar percentages of each metal.

XPS was performed on a Kratos Axis Ultra-DLD photoelectron spectrometer, using monochromated $\mathrm{Al} \mathrm{K} \alpha$ radiation, at $144 \mathrm{~W}(12 \mathrm{~mA} \times 12 \mathrm{kV})$ power. High-resolution and survey scans were performed at pass energies of 40 and $160 \mathrm{eV}$, respectively. Magnetically confined charge compensation was used to minimize sample charging, and the resulting spectra were calibrated to the $\mathrm{C}(1 \mathrm{~s})$ line at $284.8 \mathrm{eV}$.

Samples for examination by STEM were prepared by drydispersing the catalyst powder onto a holey carbon film supported by a 300 mesh copper TEM grid. Bright field (BF) and high angle annular dark field (HAADF) STEM images were taken using an aberration-corrected JEM ARM-200CF microscope operating at $200 \mathrm{kV}$. This instrument was also equipped with a JEOL Centurio silicon drift detector for X-ray energy dispersive spectroscopy (XEDS). Particle size distribution analysis was performed from analysis of the HAADF electron micrographs using ImageJ.

TPR analysis was carried out on a Thermo TPD/R/O 1100 series instrument equipped with a thermal conductivity detector (TCD). The catalyst $(50 \mathrm{mg})$ was heated to $800{ }^{\circ} \mathrm{C}$ under an atmosphere of $10 \% \mathrm{H}_{2} / \mathrm{Ar}\left(5{ }^{\circ} \mathrm{C} \min ^{-1}\right)$ after pretreatment at $110{ }^{\circ} \mathrm{C}$ in $\mathrm{Ar}$ for $45 \mathrm{~min}$. The instrument was calibrated for quantitative measurements of hydrogen consumption using different known masses of $\mathrm{CuO}$ wires. These were heated in an atmosphere of $10 \% \mathrm{H}_{2} /$ Ar to $600{ }^{\circ} \mathrm{C}\left(15^{\circ} \mathrm{C}\right.$ $\min ^{-1}$ ).

DRIFTS measurements were taken on a Bruker Tensor 27 spectrometer fitted with a mercury cadmium telluride (MCT) detector. A sample was loaded into the Praying Mantis hightemperature (HVC-DRP-4) in situ cell before exposure to $\mathrm{N}_{2}$ and then $1 \% \mathrm{CO} / \mathrm{N}_{2}$ at a flow rate of $50 \mathrm{~cm}^{3} \mathrm{~min}^{-1}$. A background spectrum was obtained using $\mathrm{KBr}$, and measurements were recorded every $1 \mathrm{~min}$ at room temperature. Once the $\mathrm{CO}$ adsorption bands in the DRIFT spectra ceased to increase in size, the gas feed was changed back to $\mathrm{N}_{2}$ and 


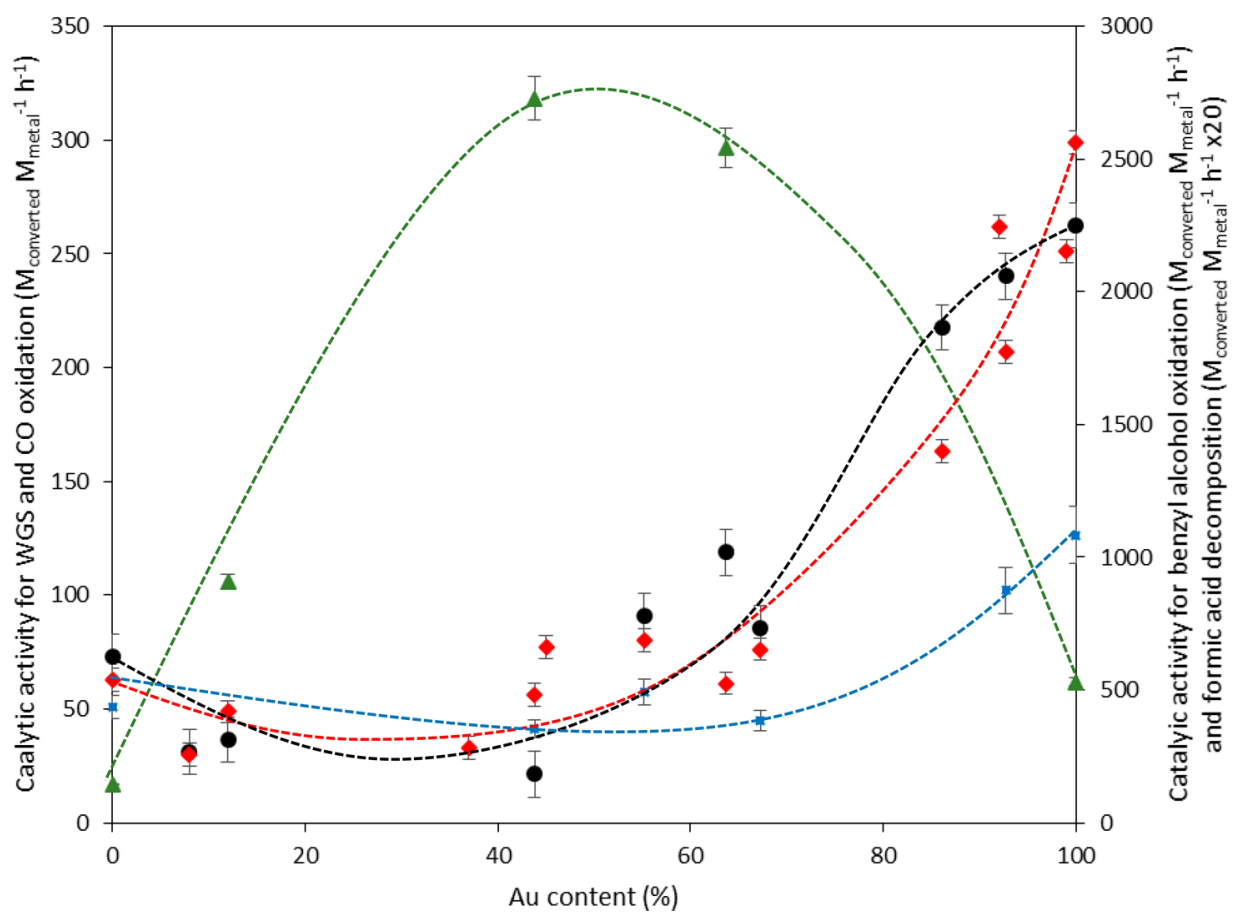

Figure 1. Catalytic activity of various $\mathrm{Au}_{x} \mathrm{Pd}_{y} / \mathrm{CeZrO}_{4}$ catalysts for water-gas shift (black $\bullet$ ), $\mathrm{CO}$ oxidation (red $\bullet$ ), formic acid decomposition (blue $\mathbf{\square}$ ), and benzyl alcohol oxidation (green $\mathbf{\Delta}$ ). Activity measurements were recorded after $1 \mathrm{~h}$ on stream.

measurements were repeated until no change in subsequent spectra was observed.

Nitrogen physisorption was performed at $-196{ }^{\circ} \mathrm{C}$ on a Quantachrome Quadrasorb SI instrument after the sample was evacuated for $2 \mathrm{~h}$ at $120{ }^{\circ} \mathrm{C}$. The surface area was calculated using Brunauer-Emmet-Teller (BET) theory over the range $P / P_{0}=0.05-0.2$.

Benzyl alcohol $(\mathrm{BzOH})$ oxidation was carried out at $120^{\circ} \mathrm{C}$ in a $50 \mathrm{~cm}^{3}$ glass stirred reactor. In a typical reaction, $0.02 \mathrm{~g}$ of catalyst and $1 \mathrm{~g}$ of substrate were charged into the reactor, which was then purged with oxygen three times before closing, and the pressure was maintained at $2 \mathrm{~atm}$. The reactor with the reaction mixture was kept in a heating block, which was preheated to the reaction temperature. The reaction mixture was stirred at $1000 \mathrm{rpm}$ using a magnetic bar inside the reactor. After $1 \mathrm{~h}$ of reaction, the stirring was stopped and the reactor was rapidly cooled in an ice bath. After cooling, the reactor was opened slowly and the contents were centrifuged. An aliquot of the clear supernatant reaction mixture $\left(0.5 \mathrm{~cm}^{3}\right)$ was diluted with mesitylene $\left(0.5 \mathrm{~cm}^{3}\right.$, external standard for GC analysis). For the analysis of the products and calculation of the mass balance, a GC (Varian Star 3800 with a $30 \mathrm{~m}$ CP-Wax $52 \mathrm{CB}$ column) fitted with a flame ionization detector (FID) was employed.

$\mathrm{CO}$ oxidation was performed in a fixed-bed flow reactor by passing a gas stream of $5000 \mathrm{ppm}$ of $\mathrm{CO}$ in synthetic air over the catalyst $(20 \mathrm{mg})$ at a flow rate of $20 \mathrm{~cm}^{3} \mathrm{~min}^{-1}$. The catalyst bed was held at $35^{\circ} \mathrm{C}$ using a silicone oil bath, and the $\mathrm{CO}$ conversion was measured using an online Varian 3800 gas chromatography instrument equipped with a thermal conductivity detector (TCD).

Water-gas shift reactions were performed in a fixed-bed flow reactor equipped with online Gasmet FT-IR. The catalyst (150 mg) was heated under $\mathrm{N}_{2}$ up to $150{ }^{\circ} \mathrm{C}$ at a ramp rate of $8{ }^{\circ} \mathrm{C}$ $\mathrm{min}^{-1}$ before switching to a feed of $2 \% \mathrm{CO}, 2 \% \mathrm{CO}_{2}, 7.5 \%$ $\mathrm{H}_{2} \mathrm{O}, 8.1 \% \mathrm{H}_{2}$, and $\mathrm{N}_{2}$ to balance. The total flow rate chosen was $100 \mathrm{~cm}^{3} \mathrm{~min}^{-1}$, which corresponded to a GHSV of 52000 $\mathrm{h}^{-1}$. An IR spectrum was measured every $1 \mathrm{~min}$, and conversion values were calculated on the basis of the measured consumption of $\mathrm{CO}$.

Formic acid decomposition was carried out using the same fixed-bed flow reactor as used for the WGS catalytic testing. A Dreschler bottle containing an aqueous solution of formic acid (10 wt \%) was cooled to $7{ }^{\circ} \mathrm{C} . \mathrm{N}_{2}$ was passed through the bottle at a rate of $100 \mathrm{~mL} \mathrm{~min}{ }^{-1}$, which gave a concentration of $1700 \mathrm{ppm}$ of formic acid with approximately $0.15 \% \mathrm{H}_{2} \mathrm{O}$ in the gas phase. Reactions were carried out at $85{ }^{\circ} \mathrm{C}$, and $0.05 \mathrm{~g}$ of catalyst was used. Gaseous products were analyzed using an online FTIR system.

To account for the variations in metal loadings between catalyst samples, the catalytic activity is expressed throughout this paper as moles of reactant converted per hour per total moles of metal on the catalyst: e.g., $\mathrm{M}_{\mathrm{CO} \text { converted }} \mathrm{h}^{-1} \mathrm{M}_{\text {metal }}{ }^{-1}$.

\section{RESULTS AND DISCUSSION}

Catalysts were tested for their activity for CO oxidation, WGS, $\mathrm{FAD}$, and benzyl alcohol oxidation under the conditions described above. A full list of the catalysts prepared and the characterization methods carried out on each sample is presented in Table S1 in the Supporting Information. The activity measurements across the range of $\mathrm{Au}-\mathrm{Pd}$ molar compositions showed significant differences, which gave rise to two different trends (Figure 1). For the gas-phase reactions (WGS, CO oxidation, and FAD), the monometallic Au catalyst was the most active catalyst tested. The introduction of even small quantities of $\mathrm{Pd}$ resulted in a large decrease in catalytic activity. The least active catalysts tested were Pd-rich bimetallic catalysts with a composition of $\mathrm{Au}_{88} \mathrm{Pd}_{12}$. Significantly, the monometallic Pd catalyst was always more active than the Pdrich alloy catalysts, forming an inverted-volcano plot across the range of bimetallic catalyst compositions tested. 


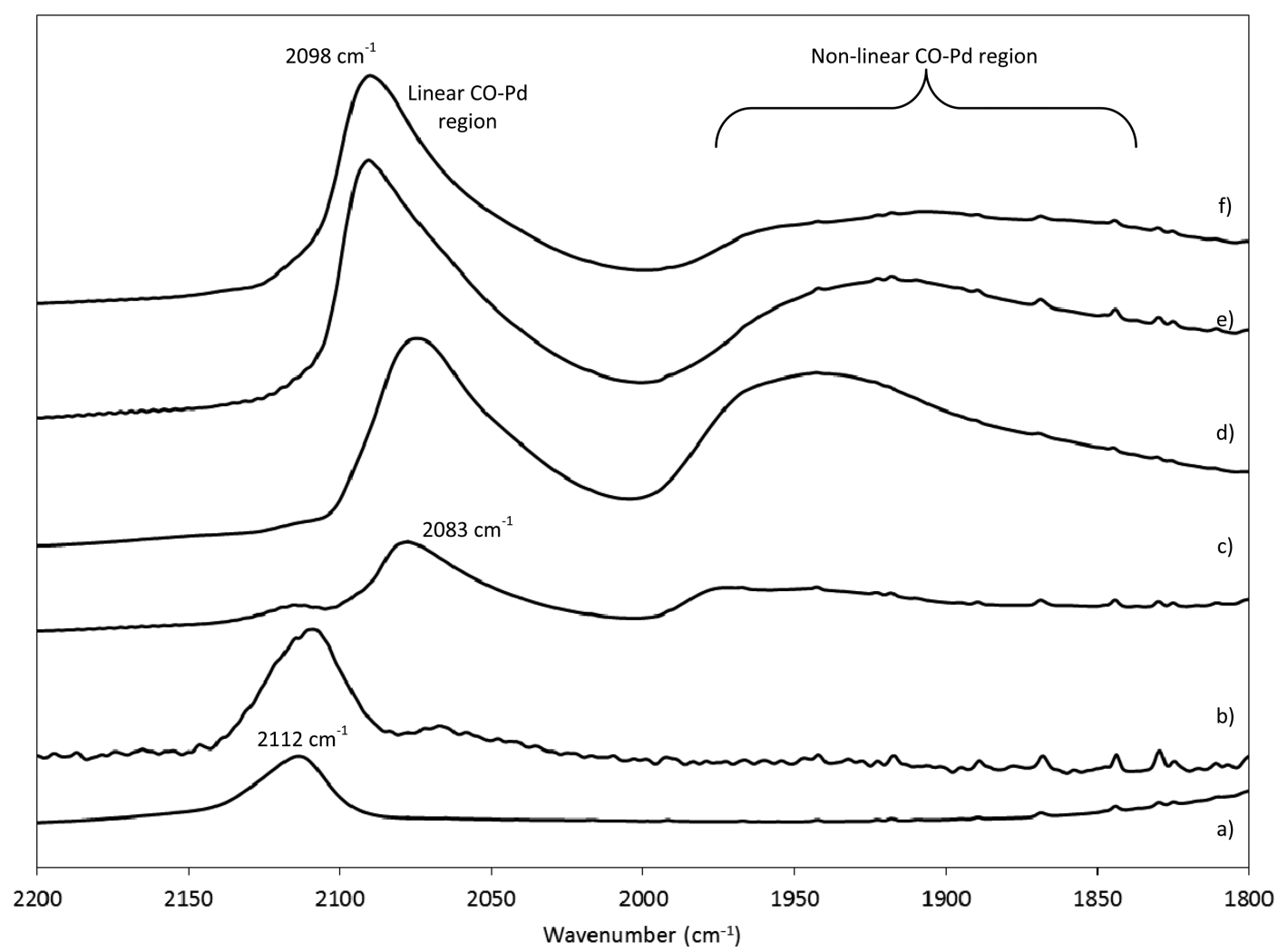

Figure 2. CO-DRIFTS spectra for selected $\mathrm{Au}-\mathrm{Pd} / \mathrm{CeZrO}_{4}$ catalysts: (a) Au; (b) $\mathrm{Au}_{93} \mathrm{Pd}_{7}$; (c) $\mathrm{Au}_{67} \mathrm{Pd}_{33}$; (d) $\mathrm{Au}_{44} \mathrm{Pd}_{56} ;(\mathrm{e}) \mathrm{Au}_{12} \mathrm{Pd}_{88} ;(\mathrm{f}) \mathrm{Pd}$

In contrast, the characteristic volcano plot expected for these materials was observed for the liquid-phase selective oxidation of benzyl alcohol (Figure 1). This confirmed the presence of the known synergistic effect and showed that these supported $\mathrm{Au}-\mathrm{Pd}$ catalysts were comparable with those previously reported for selective oxidation reactions. ${ }^{36}$

The observation that WGS, CO oxidation, and FAD have the same activity trend, across the range of $\mathrm{Au}-\mathrm{Pd}$ catalyst compositions tested, is remarkable and suggests an underlying similarity between the reaction pathways. FAD has been studied for decades, and the mechanism is well understood in comparison to that of the WGS reaction. It has been widely accepted that this reaction proceeds through an adsorbed formate, $\mathrm{HCOO}^{-}$, species. ${ }^{39-42}$ Comparisons have been made previously between WGS and FAD, notably by Davis and coworkers who studied the two reactions over $\mathrm{Pt} / \mathrm{CeO}_{2}$ catalysts using isotope exchange experiments and in situ IR spectroscopy. ${ }^{40}$ They concluded that a common reaction intermediate and analogous mechanism existed for the two reactions. Iglesia et al. compared WGS, $\mathrm{FAD}$, and $\mathrm{CO}$ oxidation on $\mathrm{Au} / \mathrm{Al}_{2} \mathrm{O}_{3}$ and with the aid of electron microscopy stated that, while WGS and $\mathrm{FAD}$ both require atoms or clusters of $\mathrm{Au}$ that were below the imaging resolution of the microscope used in their work, $\mathrm{CO}$ oxidation took place on larger, resolvable particles. ${ }^{43}$ Our current study, in contradiction to the previous report, shows that all three reactions vary in the same manner between the different formulations of $\mathrm{Au}-\mathrm{Pd}$ bimetallic catalysts, which implies that the same types of active sites are required for each reaction. One possible explanation for the discrepancies in the literature involves the support. In the report by Iglesia et al., $\mathrm{Al}_{2} \mathrm{O}_{3}$ was used as the support but this does not have the redox and $\mathrm{H}_{2} \mathrm{O}$-activation properties of $\mathrm{CeZrO}_{4}$. In order to rationalize the catalytic activity trends, the catalysts were characterized using in situ CO-DRIFTS, TPR, and XPS. Aberration-corrected STEM was also carried out on a small subset of the $\mathrm{CeZrO}_{4}$-supported catalysts to measure the particle size distributions of the supported metals and to monitor any structural variations occurring as a function of changing metal composition.

The CO-DRIFTS spectrum of each catalyst was measured in the $1800-2200 \mathrm{~cm}^{-1}$ range, which contains the stretching modes of $\mathrm{CO}$ adsorbed on $\mathrm{Au}$ and $\mathrm{Pd}$. This technique has been used extensively to probe the surface of supported preciousmetal catalysts. ${ }^{27,44-49}$ The CO-DRIFTS data for a range of $\mathrm{Au}_{x} \mathrm{Pd}_{y}$ catalysts are presented in Figure 2.

The higher wavenumber region of the spectra (2200-2000 $\mathrm{cm}^{-1}$ ) has previously been assigned to linearly adsorbed carbonyl species, while features at lower wavenumbers (2000-1800 $\mathrm{cm}^{-1}$ ) have been assigned to bridged or 3-fold adsorption of $\mathrm{CO}$ on $\mathrm{Pd}$ or $\mathrm{Au}-\mathrm{Pd} .^{48,50}$ The monometallic $\mathrm{Au}$ catalyst exhibits just one band at $2112 \mathrm{~cm}^{-1}$, caused by the linear adsorption of $\mathrm{CO}$ on $\mathrm{Au}$, consistent with previous findings. ${ }^{51}$ The monometallic $\mathrm{Pd}$ catalyst gives rise to two distinct features: first, there is an intense band at $2098 \mathrm{~cm}^{-1}$, which corresponds to the linear adsorption of $\mathrm{CO}$ at the corner or edge sites of $\mathrm{Pd}$ particles. Second, there is a broad feature beginning at $1960 \mathrm{~cm}^{-1}$, where 2 -fold and 3-fold adsorption of CO on Pd occurs. ${ }^{47,52}$ It has been experimentally demonstrated that the linear modes of $\mathrm{CO}$ adsorption on Pd are due to the adsorption of $\mathrm{CO}$ molecules at the edge of the nanoparticle, on undercoordinated Pd species. ${ }^{47,52}$ The active site of such supported catalysts is generally accepted to be at the metalsupport interface for $\mathrm{WGS}^{10}$ and CO oxidation; ${ }^{53}$ therefore, these adsorption modes are mechanistically significant for these reactions. The nonlinear adsorption modes are typically due to molecules adsorbing on extended metal surfaces such as the 

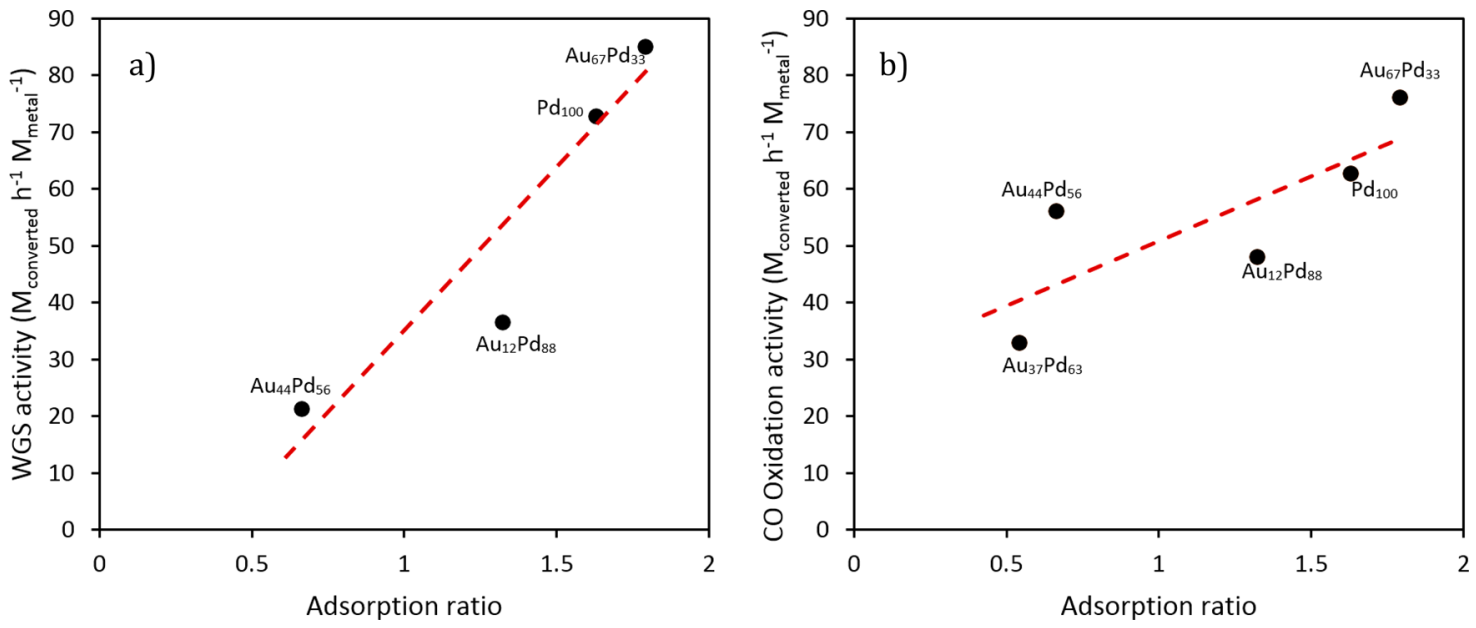

Figure 3. Relationship between the catalytic activity of $\mathrm{Au}_{x} \mathrm{Pd}_{y} / \mathrm{CeZrO} 4$ catalysts and the linear/nonlinear adsorption ratio determined from $\mathrm{CO}-$ DRIFTS analysis: (a) WGS reaction; (b) CO oxidation. Au is not shown, as the CO-adsorption spectrum is dominated by linear CO-Au species.

shell of the nanoparticle. Therefore, the relative contribution of each adsorption mode (the adsorption ratio) should provide a direct indication of the relative abundance of interfacial and surface sites. (The position of the linear Pd band, which is seen to vary systematically between $\mathrm{Au}_{x} \mathrm{Pd}_{y}$ samples, can be explained by charge transfer from $\mathrm{Au}$ to $\mathrm{Pd}$, which is an indication of the interaction between $\mathrm{Au}$ and $\mathrm{Pd}$ surface atoms. $^{49,54}$ )

The adsorption ratio was calculated from the integrated area of each spectral feature. The higher the value, the higher the contribution of interfacial sites in the sample. Therefore, it would be expected that samples with smaller particle sizes, but identical metal loadings, should exhibit higher adsorption ratios. Ouyang et al. implemented this approach to show that the dilution of $\mathrm{Pd}$ by $\mathrm{Au}$ was beneficial for the direct synthesis of hydrogen peroxide. ${ }^{49}$ As Figure 3 demonstrates, our most active $\mathrm{Au}_{x} \mathrm{Pd}_{y}$ catalysts for the gas-phase reactions had the smallest contribution from nonlinear adsorption of CO. This is clearly consistent with the active sites for these reactions being located at the metal-support interface, so that those catalysts that possess the highest relative population of periphery sites at the exposed particle/support interface (i.e., smaller particles) should be the most active. Significantly, the monometallic Pd sample had a higher adsorption ratio than any of the Pd-rich bimetallic catalysts, an observation that has been reported previously. Redina et al. examined the CO-DRIFTS spectra of 0.5 wt $\% \mathrm{Pd} / \mathrm{TiO}_{2}$ and 0.05 wt $\% \mathrm{Au}-0.5$ wt $\% \mathrm{Pd} / \mathrm{TiO}_{2}$ catalysts and found that the introduction of $\mathrm{Au}$ resulted in an increase in the nonlinear adsorption band in comparison with the linear band, consistent with these findings and indicative of a larger mean nanoparticle size. The increase in nonlinear adsorption bands for their bimetallic sample was thought to be due to bridged adsorption of $\mathrm{CO}$ on $\mathrm{Au}-\mathrm{Pd}$ species. ${ }^{50}$ Ouyang et al. also measured the ratio of the linear and nonlinear adsorption bands and found that the ratio decreases with increasing Pd content, all the way up to monometallic Pd, although those catalysts were prepared by incipient-wetness impregnation and were calcined and reduced prior to analysis. ${ }^{49}$

Zhu et al. conducted a combined DFT and DRIFTS study that investigated the mobility and stability of $\mathrm{Pd}$ in $\mathrm{Au}-\mathrm{Pd}$ nanoclusters in the presence of $\mathrm{CO}{ }^{27}$ Their findings showed that $\mathrm{Pd}$ preferentially occupies undercoordinated edge sites and it is these Pd species that strongly adsorb CO. Therefore, the presence of $\mathrm{Pd}$ at the surface causes $\mathrm{CO}$ to preferentially adsorb on Pd, rather than on Au. This explains why the introduction of Pd leads to such a rapid decrease in activity for $\mathrm{CO}$ oxidation and water-gas shift reactions: first, more surface Pd atoms means that there are fewer "highly active" Au sites onto which the $\mathrm{CO}$ can adsorb, and second, the stronger affinity of $\mathrm{CO}$ for $\mathrm{Pd}$ means that the $\mathrm{CO}$ preferentially adsorbs onto a Pd site rather than an $\mathrm{Au}$ site. This is illustrated in Figure 2, which shows the DRIFT spectrum of $\mathrm{Au}_{67} \mathrm{Pd}_{33} / \mathrm{CeZrO}_{4}$ which is dominated by $\mathrm{CO}-\mathrm{Pd}$ adsorption modes, indicative of a $\mathrm{Pd}$ rich catalyst surface.

As the reducibility of both ceria and ceria-zirconia have been extensively studied in the past, ${ }^{55-57} \mathrm{H}_{2}$-TPR was used to probe the redox properties of the catalysts, as shown in Figure 4. Our bare $\mathrm{CeZrO}_{4}$ support exhibits a low-temperature reduction peak at $\sim 350{ }^{\circ} \mathrm{C}$ and another peak at $550{ }^{\circ} \mathrm{C}$, which correspond to the surface and bulk reduction of the metal oxide, respectively, which is consistent with previous literature data. ${ }^{56}$ The lowest-temperature feature on the bare support material occurs at $\sim 125{ }^{\circ} \mathrm{C}$ and is most likely a contribution from a surface-adsorbed species such as a carbonate. ${ }^{58}$ The addition of $\mathrm{Au}$ and/or Pd facilitates the surface reduction of the $\mathrm{CeZrO}_{4}$ support with peaks appearing at 167 and $97^{\circ} \mathrm{C}$ for the monometallic $\mathrm{Au}$ - and $\mathrm{Pd}$-supported catalysts, respectively. This phenomenon has been attributed either to spillover of dissociated hydrogen from the precious metal to the support ${ }^{59}$ or to an electronic metal-support interaction that promotes the reducibility of the support. ${ }^{60}$ The series of bimetallic AuPd catalysts exhibits a low-temperature reduction peak closer to that of pure $\mathrm{Pd}$, even for the $\mathrm{Au}_{86} \mathrm{Pd}_{14}$ catalyst, suggesting that even a small quantity of $\mathrm{Pd}$ results in an enhancement in catalyst support reducibility. No correlation could be found in our systematic sample set between the temperature of reduction and catalytic activity displayed for the WGS reaction. This suggests that the mechanistic steps that are facilitated by the redox properties of the support, such as the activation of $\mathrm{H}_{2} \mathrm{O}$, are not rate-limiting for these catalysts. This finding is consistent with previous work which has shown that on a $\mathrm{CeO}_{2}$ support having a surface area above $90 \mathrm{~m}^{2} \mathrm{~g}^{-1}$ there are sufficient $\mathrm{H}_{2} \mathrm{O}$ activation sites to make $\mathrm{CO}$ activation more rate controlling. ${ }^{61}$ The surface area of the $\mathrm{CeZrO}_{4}$ used in this work as measured using $\mathrm{N}_{2}$ physisorption was $130 \mathrm{~m}^{2} \mathrm{~g}^{-1}$. It should be noted, however, that the $\mathrm{H}_{2}$-TPR does show a correlation 


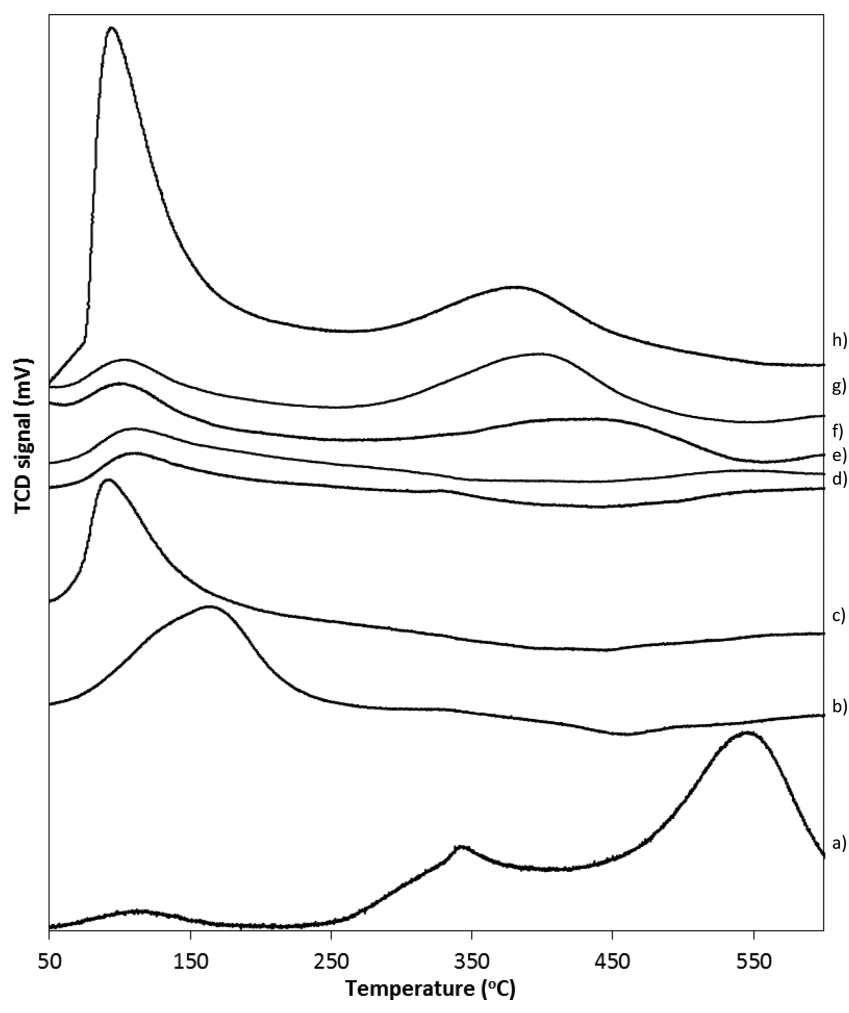

Figure 4. $\mathrm{H}_{2}$-TPR traces of the $\mathrm{Au}_{x} \mathrm{Pd}_{y} / \mathrm{CeZrO}_{4}$ catalysts: (a) $\mathrm{CeZrO}_{4}$ only; (b) Au; (c) $\mathrm{Au}_{86} \mathrm{Pd}_{14}$; (d) $\mathrm{Au}_{67} \mathrm{Pd}_{33}$; (e) $\mathrm{Au}_{44} \mathrm{Pd}_{56}$; (f) $\mathrm{Au}_{12} \mathrm{Pd}_{86}$; (g) $\mathrm{Au}_{8} \mathrm{Pd}_{92} ;(\mathrm{h}) \mathrm{Pd}$.

between the amount of hydrogen consumed by the catalysts and the catalytic activity for CO oxidation and WGS (Figure 5). With the exception of the supported monometallic Pd catalyst, samples that consumed more hydrogen exhibited a higher catalytic activity. This observation could simply reflect the differences in the metal dispersion of each catalyst, such that the larger interface (as detected by the $\mathrm{CO}$ adsorption ratio) resulted in more hydrogen spillover or a higher degree of electronic metal-support interaction. However, as discussed below, this explanation does not take into account the metal composition at the periphery of the nanoparticles. The low activity of the Pd-only catalyst, despite its high consumption of hydrogen, again is consistent with the strong binding strength of $\mathrm{CO}$ on Pd.

XPS analysis of the $\mathrm{Au}_{x} \mathrm{Pd}_{y}$ catalysts, summarized in Table 1 , was used to gain information primarily on the oxidation state of
Table 1. XPS analysis of the range of AuxPdy/CeZrO4 samples showing surface concentration and the binding energies of different $\mathrm{Au}$ and Pd species

\begin{tabular}{|c|c|c|c|c|c|c|c|}
\hline \multirow[b]{2}{*}{ catalyst } & \multicolumn{3}{|c|}{$\begin{array}{c}\text { composition of } \\
\text { different } \mathrm{Au} \text { species } \\
\mathrm{CeZrO}_{4} \text { catalysts }(\%)\end{array}$} & \multicolumn{4}{|c|}{ binding energy $(\mathrm{eV})$} \\
\hline & $\mathrm{Au}^{0}$ & $\mathrm{Au}^{0 *}$ & $\overline{\mathrm{Au}^{3+}}$ & $\mathrm{Au}^{0}$ & $\mathrm{Au}^{0 *}$ & $\mathrm{Au}^{3+}$ & $\mathrm{Pd}^{2+}$ \\
\hline $\mathrm{Au}$ & 65 & 27 & 8 & 84.1 & 85.2 & 86.6 & \\
\hline $\mathrm{Au}_{86} \mathrm{Pd}_{14}$ & 76 & 16 & 8 & 83.9 & 85.1 & 86.5 & 337.9 \\
\hline $\mathrm{Au}_{67} \mathrm{Pd}_{33}$ & 82 & 12 & 5 & 83.9 & 85.1 & 86.2 & 337.7 \\
\hline $\mathrm{Au}_{64} \mathrm{Pd}_{36}$ & 82 & 13 & 6 & 83.8 & 84.9 & 86.2 & 337.6 \\
\hline $\mathrm{Au}_{55} \mathrm{Pd}_{45}$ & 77 & 15 & 8 & 84.1 & 85.2 & 86.6 & 337.7 \\
\hline $\mathrm{Au}_{44} \mathrm{Pd}_{56}$ & 89 & 8 & 4 & 83.8 & 85.1 & 86.6 & 337.5 \\
\hline $\mathrm{Au}_{12} \mathrm{Pd}_{88}$ & 72 & 18 & 11 & 83.8 & 84.9 & 86.3 & 337.6 \\
\hline $\mathrm{Au}_{8} \mathrm{Pd}_{92}$ & 75 & 13 & 12 & 83.6 & 84.7 & 86.3 & 337.6 \\
\hline $\mathrm{Pd}$ & & & & & & & 337.6 \\
\hline
\end{tabular}

the $\mathrm{Au}$. It should be noted that the binding energy of the $\mathrm{Au}$ $4 \mathrm{f}_{7 / 2}$ signal in each catalyst varied according to the Au:Pd ratio, whereby increasing $\mathrm{Pd}$ content resulted in a lower $\mathrm{Au} 4 \mathrm{f}_{7 / 2}$ binding energy, with the most pronounced shift occurring in the $\mathrm{Au}_{8} \mathrm{Pd}_{92}$ catalyst, which exhibited a peak at $83.6 \mathrm{eV}$ in comparison to $84.1 \mathrm{eV}$ in the monometallic Au catalyst. This $\mathrm{Au} 4 \mathrm{f}_{7 / 2}$ shift is due to the electronic modification of the $\mathrm{Au}$ species by $\mathrm{Pd}$ and indicates a close interaction between the $\mathrm{Au}$ and the Pd. ${ }^{25,62}$ Similar trends have been observed on $\mathrm{SiO}_{2}$ supported $\mathrm{Au}-\mathrm{Pd}$ catalysts, although the magnitudes of such binding energy shifts were different. ${ }^{25}$ The magnitude and direction of the binding energy shift are dependent on both initial and final state effects, the former of which is affected by the catalyst support; ${ }^{63}$ therefore, quantitative comparisons between $\mathrm{Au}-\mathrm{Pd}$ catalysts on different supports are not meaningful. Analogous shifts in the binding energy of the Pd species were also observed and are shown in Table 1 .

Figure 6 shows a montage of the peak-fitted Au 4f XP spectra. Fitting of the spectra revealed that the oxidation states of $\mathrm{Au}$ varied significantly across the range of $\mathrm{Au}_{x} \mathrm{Pd}_{y}$ catalysts, as shown in Table 1. A summary of the relative proportions of different $\mathrm{Au}$ species present are also summarized in Table 1 . In the $\mathrm{Au}$ and $\mathrm{AuPd}$ catalysts, there was evidence of $\mathrm{Au}^{0}$ and $\mathrm{Au}^{3+}$ species which correspond to peaks with binding energies of 84.1 and $86.6 \mathrm{eV}$, respectively, for the $\mathrm{Au}$ catalyst. ${ }^{64-66}$ In addition, there was evidence of an additional species at $85.1 \mathrm{eV}$, labeled $\mathrm{Au}^{0 *}$. When the concentrations of $\mathrm{Au}^{0}, \mathrm{Au}^{0 *}$, and $\mathrm{Au}^{3+}$ are compared with the catalytic activity in WGS and CO oxidation (Figure 7), a strong correlation emerges: catalysts
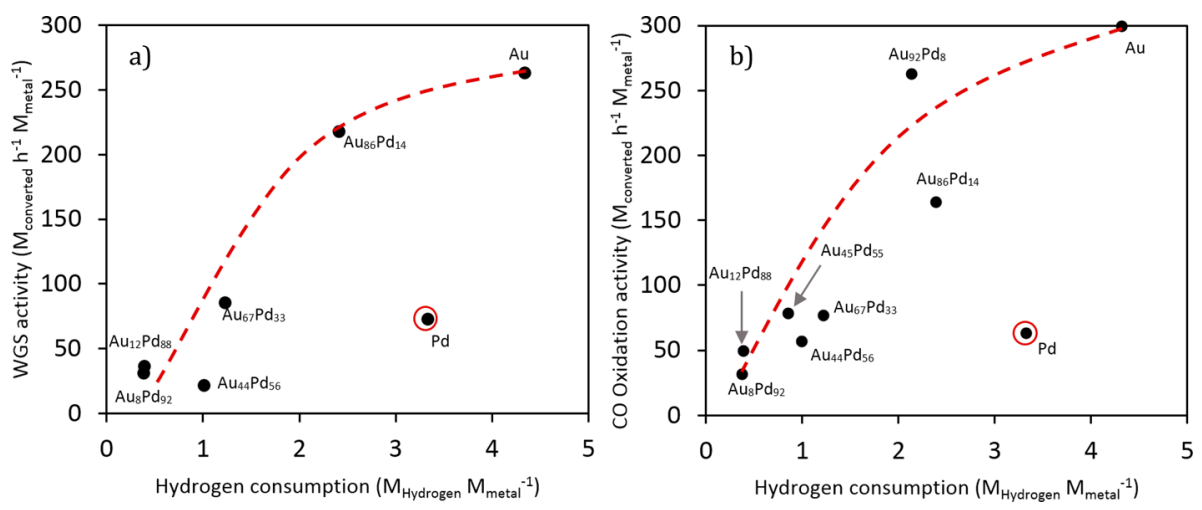

Figure 5. Correlation between activity and hydrogen consumption for $\mathrm{Au}_{x} \mathrm{Pd}_{y} / \mathrm{CeZrO}_{4}$ catalysts: (a) WGS reaction; (b) CO oxidation. 


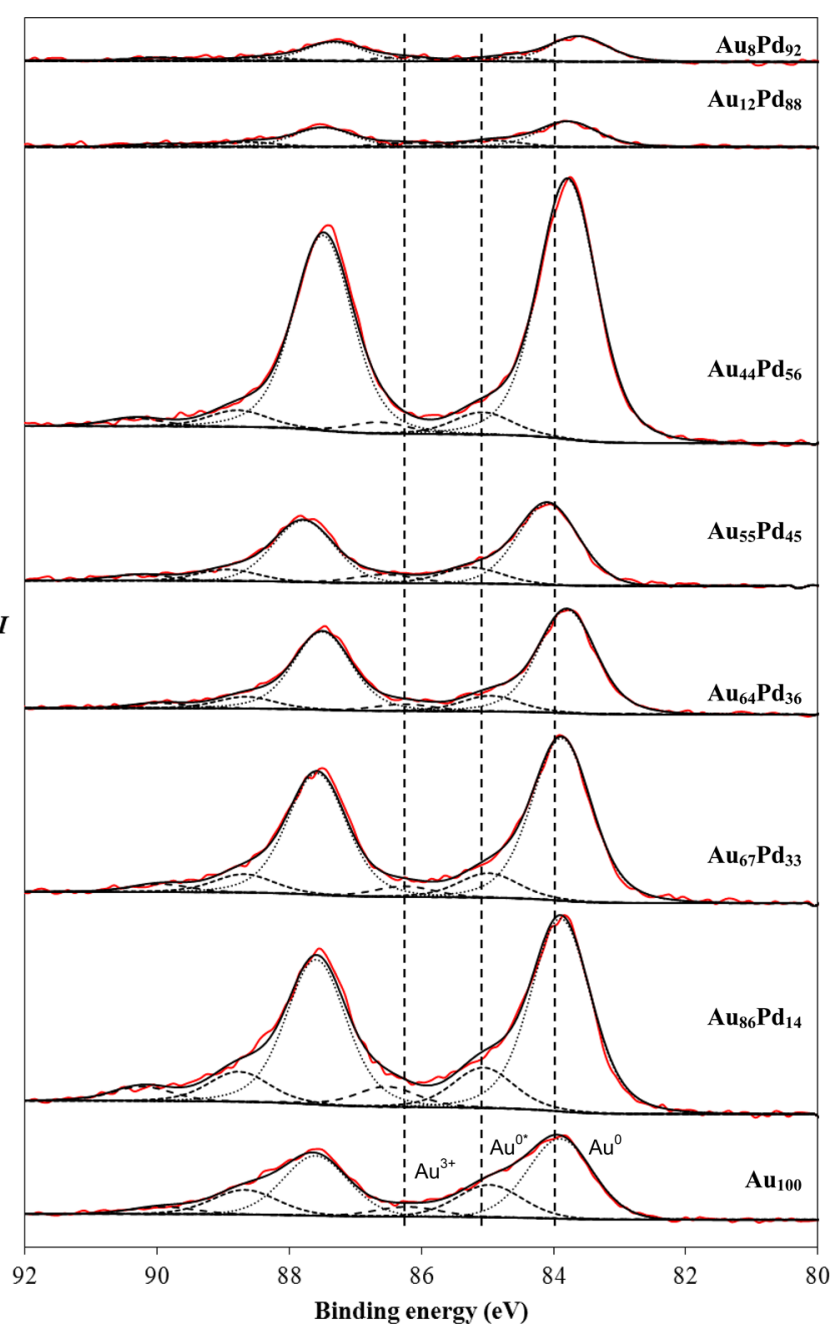

Figure 6. XPS analysis of $\mathrm{Au} 4 \mathrm{f}$ spectra showing the deconvolution of peaks for a selection of $\mathrm{Au}_{x} \mathrm{Pd}_{y}$ catalysts.

with higher concentrations of $\mathrm{Au}^{0 *}$ are much more active than those with a smaller proportion of $\mathrm{Au}^{0} *$. The assignment of the feature at $85.1 \mathrm{eV}$ remains controversial. Some previous investigations have assigned this feature to ionic gold, ${ }^{67}$ while many others have interpreted this species to be due to small gold nanoparticles, ${ }^{68-73}$ with Radnik et al. revealing that significant shifts in the binding energy are observed in gold particles below $10 \mathrm{~nm}^{74}$ The STEM-HAADF images and particle size distributions obtained for the samples in this work (Figures 8-12) in fact show an abundance of small nanoparticles, and thus the assignment of the peak at 85.1 $\mathrm{eV}$, labeled as $\mathrm{Au}^{0 *}$, as being due to the presence of small nanoparticles appears to be more plausible. The monometallic $\mathrm{Au}$ exhibited the highest proportion of $\mathrm{Au}^{0} *$ in the sample, with $27 \%$ of the detected gold originating from this species. As the Pd content increased, a significant decrease in the proportion of $\mathrm{Au}^{0 *}$ was observed, which could indicate larger particle sizes. The XPS data presented here are consistent with the TPR data described earlier, providing further evidence to suggest that significant variations in metal particle size occur across this range of $\mathrm{Au}_{x} \mathrm{Pd}_{y}$ catalysts. It should be noted that the same catalysts that consumed large quantities of hydrogen in the TPR experiments were also observed to have a large amount of $\mathrm{Au}^{0}$ * present according to XPS analysis.

Figure 8 shows representative STEM images of the dispersion and nature of the metal nanoparticles in the unused
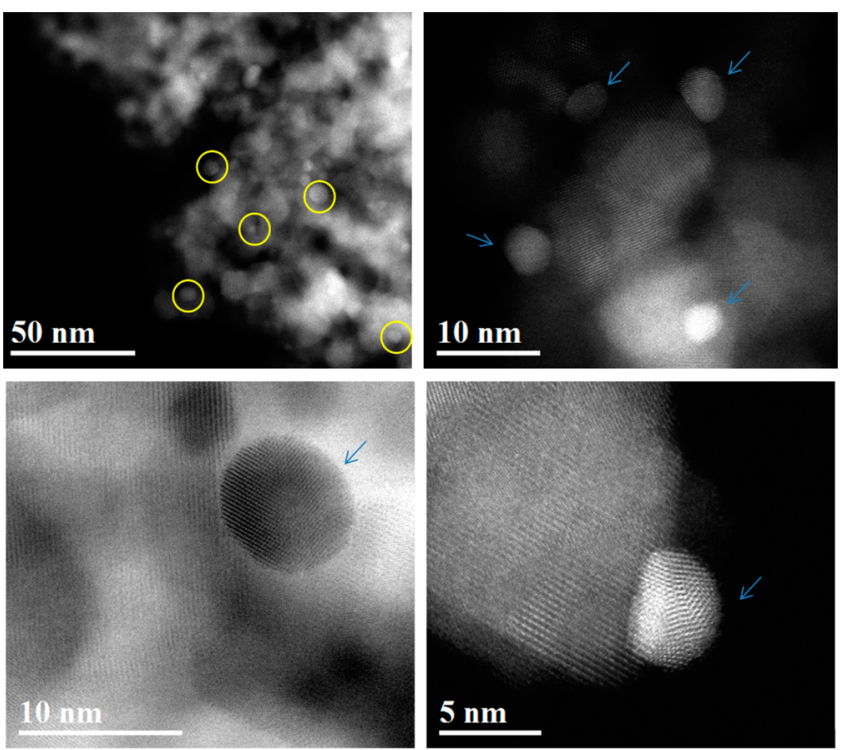

Figure 8. Representative BF- and HAADF-STEM images of the unused monometallic Au catalyst.
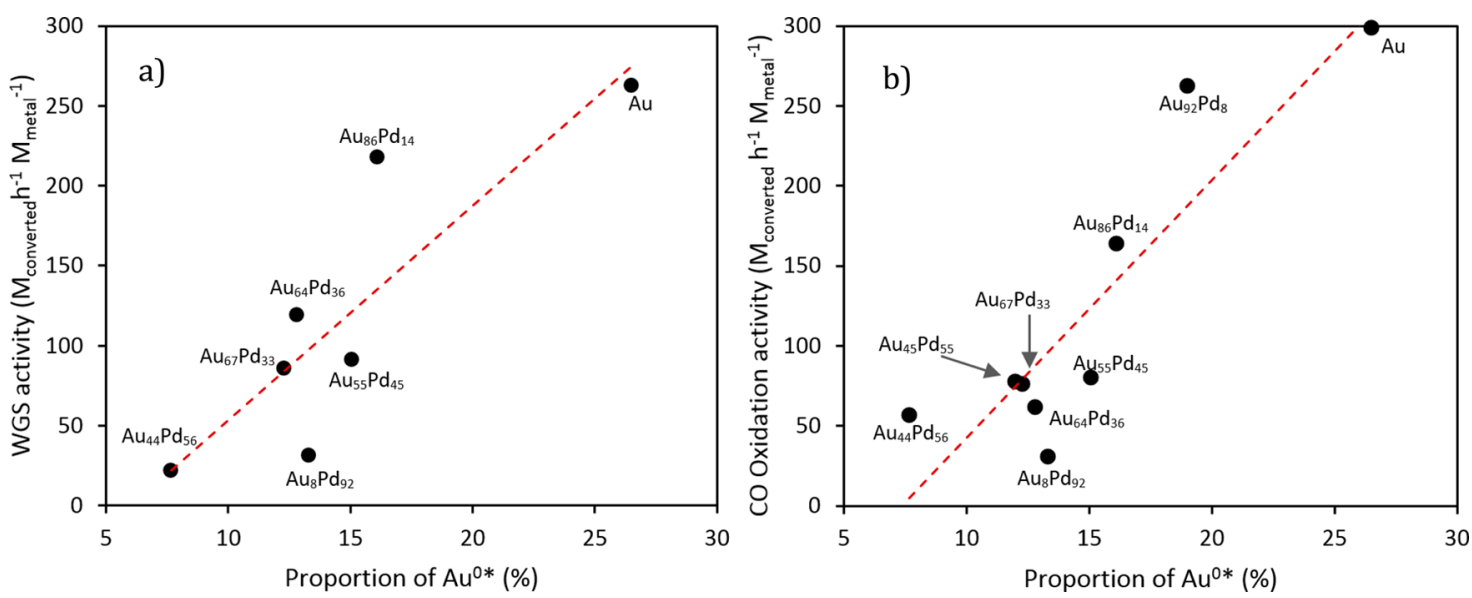

Figure 7. Correlation between the concentration of $\mathrm{Au}^{0 *}$ and the catalytic activity in (a) WGS reaction, (b) CO oxidation. 
Au catalyst. The primarily cuboctahedral Au particles tend to exhibit distinct $\{111\}$ and $\{200\}$-type surface facets and form planar interfaces with the mixed oxide support grains (Figure $8 \mathrm{~b}-\mathrm{d})$. A particle size histogram derived from HAADF image measurements on several hundred Au particles is presented in Figure 12a and shows that the $\mathrm{Au}$ particles have a mean size of $\sim 4.45 \mathrm{~nm}$.

Figures 9 and 10 show corresponding electron microscopy data from the unused bimetallic $\mathrm{Au}_{93} \mathrm{Pd}_{7}$ and $\mathrm{Au}_{55} \mathrm{Pd}_{45}$ samples,
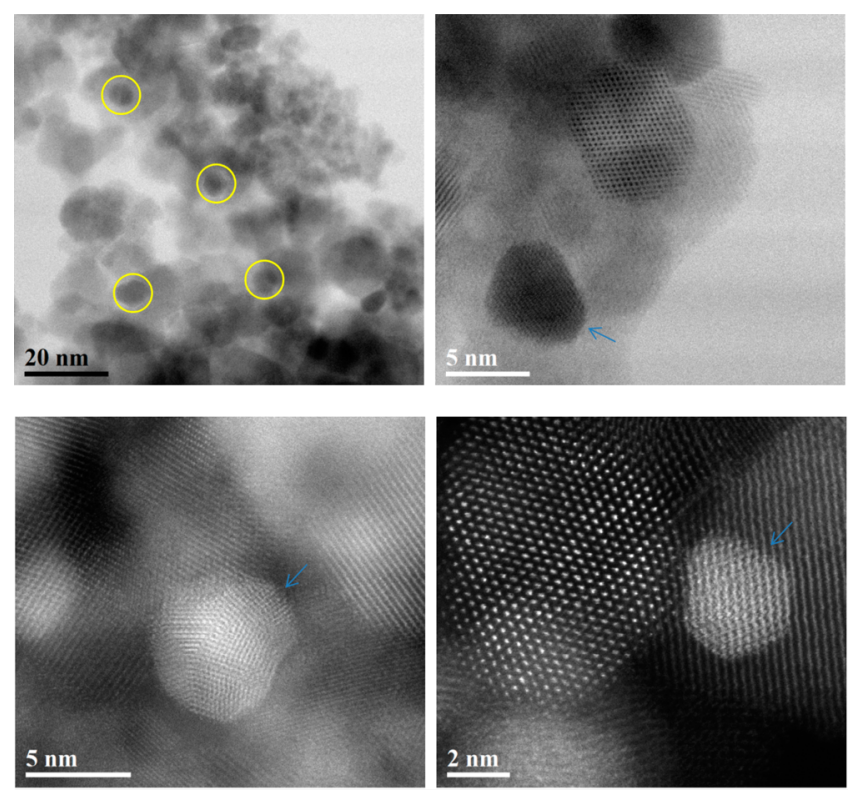

Figure 9. Representative BF- and HAADF-STEM images of the unused bimetallic $\mathrm{Au}_{93} \mathrm{Pd}_{7}$ catalyst.
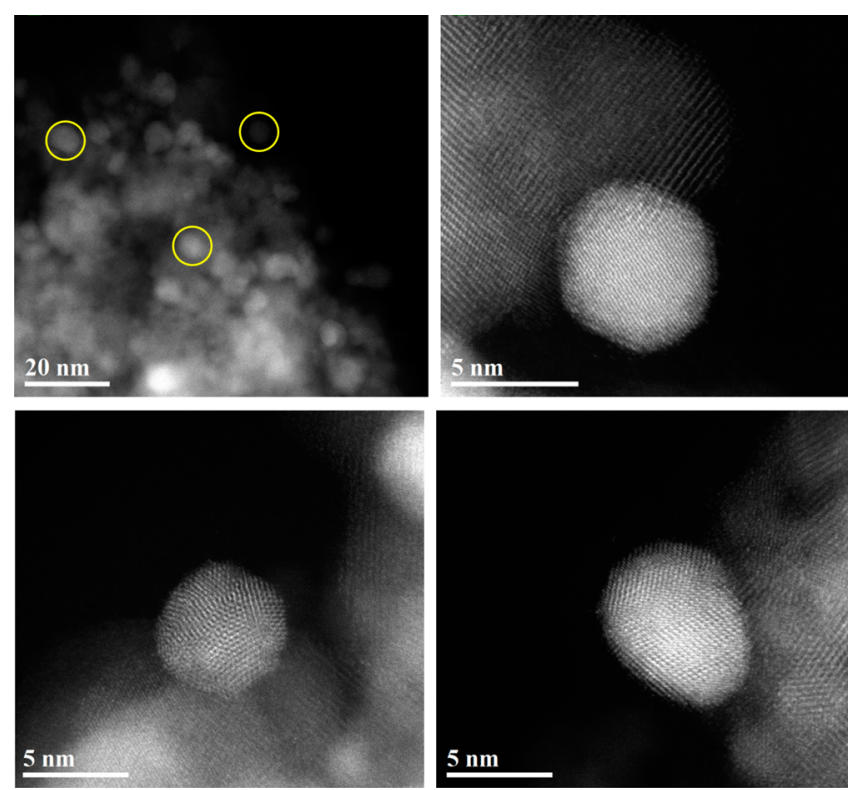

Figure 10. Representative BF- and HAADF-STEM images of the unused bimetallic $\mathrm{Au}_{55} \mathrm{Pd}_{45}$ catalyst.

respectively. The supported metal nanoparticles in both cases were a mixture of cuboctahedral and icosahedral morphologies. Furthermore, the metal particles in both samples were confirmed by XEDS analysis to be random alloys of $\mathrm{Au}$ and Pd. They also showed evidence of distinct surface faceting and extended flat interfaces with the $\mathrm{CeZrO}_{4}$ support grains. It is apparent that the addition of $\mathrm{Pd}$ to $\mathrm{Au}$ causes a significant increase in mean particle size. The addition of only $5 \% \mathrm{Pd}$ to $\mathrm{Au}$ increases the mean particle size from 4.45 to $6.15 \mathrm{~nm}$ (Figure $12 \mathrm{~b}$ ). Increasing the $\mathrm{Pd}$ fraction up to $45 \%$ in the alloy causes a small additional increase in mean size to $6.45 \mathrm{~nm}$ (Figure 12c).

Figure 11 shows some representative STEM images of the unused monometallic Pd catalyst. In this case, the supported

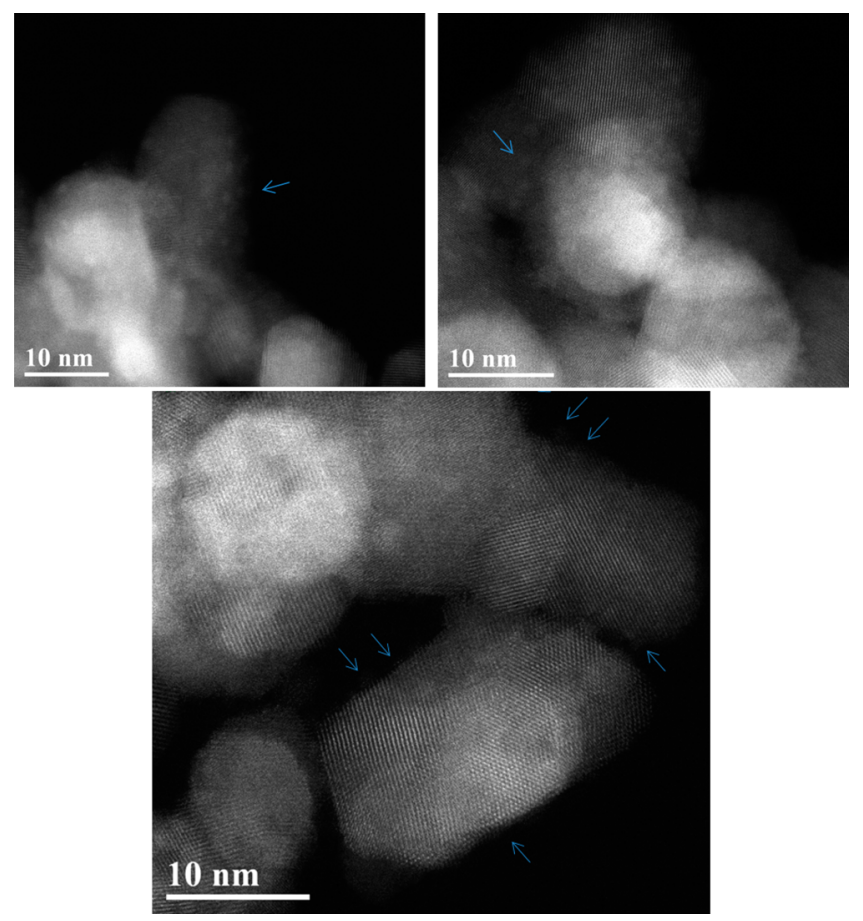

Figure 11. Representative BF- and HAADF-STEM images of the unused monometallic Pd catalyst.

particles were much harder to visualize, as they were much smaller than the corresponding $\mathrm{Au}$ or $\mathrm{Au}-\mathrm{Pd}$ particles and exhibited poorer mass contrast against the $\mathrm{CeZrO}_{4}$ support grains. In fact, as no lattice fringes were visible, it is impossible to ascertain if they were $\mathrm{Pd}$ or $\mathrm{PdO}_{x}$. Careful measurement of particle size from HAADF-STEM images showed them to have a mean size of only $1.28 \mathrm{~nm}$ (Figure 12d). Overall, the particle size distributions measured using HAADF-STEM are entirely consistent with the spectroscopic and TPR data presented earlier, which indicate that the average particle size of the bimetallic catalysts is larger than that of the monometallic catalysts.

\section{CONCLUSIONS}

We have shown that the introduction of Pd into Au catalystsintended to enhance activity and therefore allow the catalysts to be operated at lower temperatures that favor increased stability - is very detrimental to the catalytic activity for WGS, FAD, and $\mathrm{CO}$ oxidation. Instead of the volcano plot observed for benzyl alcohol oxidation to benzaldehyde, each of the gas-phase reactions showed an inverse dependence on Pd content up to about $30 \mathrm{~mol} \%$, before the activity stabilized. Although this anti-synergy showed a dependence on nanoparticle size, as revealed by the ex situ techniques, in situ CODRIFTS appears to detect the relative populations of the 
$\mathbf{a}$

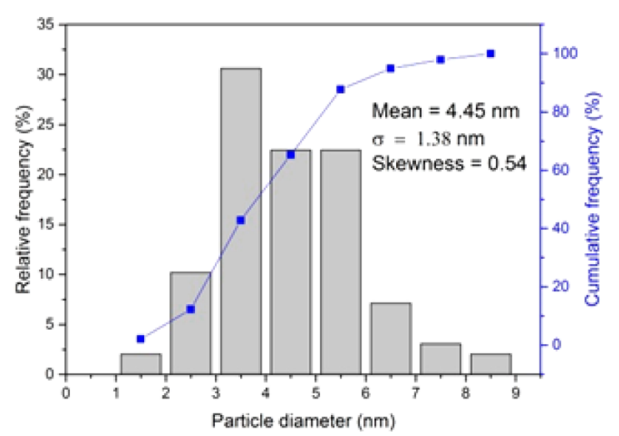

c

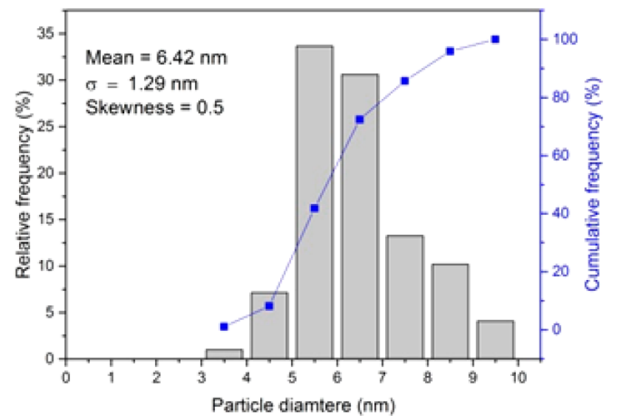

b

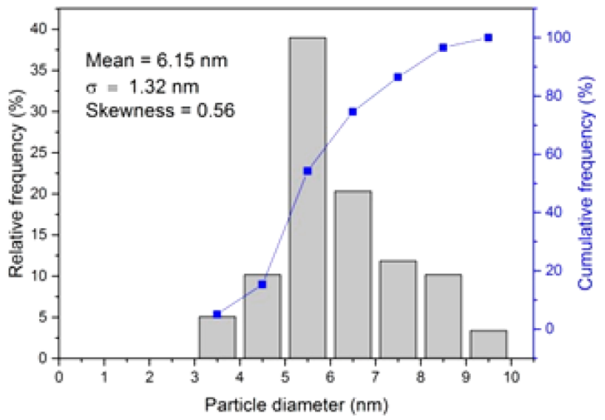

d

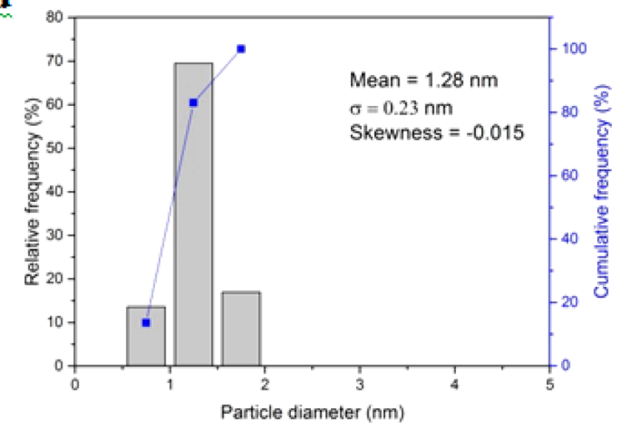

Figure 12. Particle size distribution histograms derived from HAADF-STEM images for the (a) $\mathrm{Au},(\mathrm{b}) \mathrm{Au}_{93} \mathrm{Pd}_{7},(\mathrm{c}) \mathrm{Au}_{55} \mathrm{Pd}_{45}$ and $(\mathrm{d}) \mathrm{Pd}$ catalyst samples in the unused state.

metal-support periphery adsorption sites and the adsorption sites on top of the metal particles. This technique proved to be predictive for catalytic activity for WGS, FAD, and $\mathrm{CO}$ oxidation, which not only supports the notion that the interfacial sites at the metal-support periphery sites are the most active but is also consistent with the notion that each of these three reactions require similar active sites. XPS analysis showed that those samples that exhibited a high proportion of $\mathrm{Au}^{0 *}$ species also exhibited a high activity for the three antisynergistic reactions.

The electronic interaction between $\mathrm{Pd}$ and $\mathrm{Au}$, which is used to explain the synergy observed for selective oxidation reactions, ${ }^{7}$ clearly does not have a significant role in WGS, $\mathrm{FAD}$, and $\mathrm{CO}$ oxidation under low-temperature gas-phase conditions. Instead, the metal species at the periphery of the supported nanoparticles are implicated in these reactions. Rather than describe these species as the active sites, it is probably more accurate to consider them as components of active centers that are comprised of metal atoms (at the periphery of the nanoparticles) in close proximity to adsorption sites on the support material. Thus in the case of the WGS reaction, for example, $\mathrm{CO}$ adsorbed on peripheral metal sites can interact with adjacent hydroxyl species formed by the activation of $\mathrm{H}_{2} \mathrm{O}$ on the support. In this way, the reaction proceeds via a Langmuir-Hinshelwood mechanism across the metal-support interface. Maximizing and preserving this interface are, therefore, key objectives in the design of more active and durable catalysts for WGS and the other related reactions, which could be integral in catalytic systems for delivering uncontaminated hydrogen to low-temperature fuel cells. The use of Pd to stabilize ultrasmall metallic gold particles on $\mathrm{CeZrO}_{4}$, and hence maximize the interface between $\mathrm{Au}^{0}$ * and the support, is not effective in this role, however. The addition of Pd during preparation of the catalysts results both in the formation of larger metal nanoparticles and in the lessactive $\mathrm{Pd}$ sites predominating at the metal-support interface.

\section{ASSOCIATED CONTENT}

\section{S Supporting Information}

The Supporting Information is available free of charge on the ACS Publications website at DOI: 10.1021/acscatal.6b01275.

Matrix showing measured catalyst composition and the catalyst testing and characterization carried out on each sample. (PDF)

\section{AUTHOR INFORMATION}

\section{Corresponding Author}

*E-mail for G.J.H.: hutch@cardiff.ac.uk.

\section{Notes}

The authors declare no competing financial interest.

\section{ACKNOWLEDGMENTS}

The authors acknowledge funding from the European Research Council (“After the Goldrush” ERC-2011-AdG-291319).

\section{REFERENCES}

(1) Hutchings, G. J. J. Catal. 1985, 96, 292-295.

(2) Haruta, M.; Kobayashi, T.; Sano, H.; Yamada, N. Chem. Lett. 1987, 16, 405-408.

(3) Andreeva, D.; Idakiev, V.; Tabakova, T.; Andreev. J. Catal. 1996, $158,354-355$.

(4) Corma, A.; Serna, P. Science 2006, 313, 332-334.

(5) Hughes, M. D.; Xu, Y. J.; Jenkins, P.; McMorn, P.; Landon, P.; Enache, D. I.; Carley, A. F.; Attard, G. A.; Hutchings, G. J.; King, F.; Stitt, E. H.; Johnston, P.; Griffin, K.; Kiely, CJ. Nature 2005, 437, $1132-1135$

(6) Edwards, J. K.; Solsona, B. E.; Landon, P.; Carley, A. F.; Herzing, A.; Kiely, C. J.; Hutchings, G. J. J. Catal. 2005, 236, 69-79. 
(7) Enache, D. I.; Edwards, J. K.; Landon, P.; Solsona-Espriu, B.; Carley, A. F.; Herzing, A. A.; Watanabe, M.; Kiely, C. J.; Knight, D. W.; Hutchings, G. J. Science 2006, 311, 362-365.

(8) Bianchi, C. L.; Canton, P.; Dimitratos, N.; Porta, F.; Prati, L. Catal. Today 2005, 102-103, 203-212.

(9) Han, Y. F.; Wang, J. H.; Kumar, D.; Yan, Z.; Goodman, D. W. J. Catal. 2005, 232, 467-475.

(10) Tibiletti, D.; Amieiro-Fonseca, A.; Burch, R.; Chen, Y.; Fisher, J. M.; Goguet, A.; Hardacre, C.; Hu, P.; Thompsett. J. Phys. Chem. B 2005, 109, 22553-22559.

(11) Goguet, A.; Burch, R.; Chen, Y.; Hardacre, C.; Hu, P.; Joyner, R. W.; Meunier, F. C.; Mun, B. S.; Thompsett, A.; Tibiletti, D. J. Phys. Chem. C 2007, 111, 16927-16933.

(12) Andreeva, D.; Kantcheva, M.; Ivanov, I.; Ilieva, L.; Sobczak, J. W.; Lisowski, W. Catal. Today 2010, 158, 69-77.

(13) Meunier, F. C.; Reid, D.; Goguet, A.; Shekhtman, S.; Hardacre, C.; Burch, R; Deng, W.; Flytzani-Stephanopoulos, M. J. Catal. 2007, 247, 277-287.

(14) Liang, S.; Veser, G. Catal. Lett. 2012, 142, 936-945.

(15) Si, R.; Tao, J.; Evans, J.; Park, J. B.; Barrio, L.; Hanson, J. C.; Zhu, Y.; Hrbek, J.; Rodriguez, J. A. J. Phys. Chem. C 2012, 116, 2354723555.

(16) Vecchietti, J.; Collins, S.; Jose Delgado, J.; Malecka, M.; del Rio, E.; Chen, X.; Bernal, S.; Bonivardi, A. Top. Catal. 2011, 54, 201-209.

(17) Centeno, M. A.; Hadjiivanov, K.; Venkov, T.; Klimev, H.; Odriozola, J. A. J. Mol. Catal. A: Chem. 2006, 252, 142-149.

(18) Ramirez Reina, T.; Ivanova, S.; Jose Delgado, J.; Ivanov, I.; Idakiev, V.; Tabakova, T.; Angel Centeno, M.; Antonio Odriozola, J. ChemCatChem 2014, 6, 1401-1409.

(19) Tabakova, T.; Manzoli, M.; Paneva, D.; Boccuzzi, F.; Idakiev, V.; Mitov, I. Appl. Catal., B 2011, 101, 266-274.

(20) Ma, C. Y.; Li, X. H.; Jin, M. S.; Liao, W. P.; Guan, R. G.; Suo, Z. H. Chin. J. Catal. 2007, 28, 535-540.

(21) Qian, K.; Huang, W. Catal. Today 2011, 164, 320-324.

(22) Schubert, M. M.; Hackenberg, S.; van Veen, A. C.; Muhler, M.;

Plzak, V.; Behm, R. J. J. Catal. 2001, 197, 113-122.

(23) Comotti, M.; Li, W. C.; Spliethoff, B.; Schuth, F. J. Am. Chem. Soc. 2006, 128, 917-924.

(24) Olmos, C. M.; Chinchilla, L. E.; Delgado, J. J.; Hungria, A. B.; Blanco, G.; Calvino, J. J.; Chen, X. W. Catal. Lett. 2016, 146 (1), 144156.

(25) Venezia, A. M.; Liotta, L. F.; Pantaleo, G.; La Parola, V.; Deganello, G.; Beck, A.; Koppany, Z.; Frey, K.; Horvath, D.; Guczi, L. Appl. Catal., A 2003, 251, 359-368.

(26) Beck, A.; Horvath, A.; Schay, Z.; Stefler, G.; Koppany, Z.; Sajo, I.; Geszti, O.; Guczi, L. Top. Catal. 2007, 44, 115-121.

(27) Zhu, B.; Thrimurthulu, G.; Delannoy, L.; Louis, C.; Mottet, C.; Creuze, J.; Legrand, B.; Guesmi, H. J. Catal. 2013, 308, 272-281.

(28) Lopez-Sanchez, J. A.; Dimitratos, N.; Glanville, N.; Kesavan, L.; Hammond, C.; Edwards, J. K.; Carley, A. F.; Kiely, C. J.; Hutchings, G. J. Appl. Catal., A 2011, 391, 400-406.

(29) Ham, H. C.; Stephens, J. A.; Hwang, G. S.; Han, J.; Nam, S. W.; Lim, T. H. J. Phys. Chem. Lett. 2012, 3, 566-570.

(30) Gao, F.; Wang, Y.; Goodman, D. W. J. Am. Chem. Soc. 2009, 131, 5734-5735.

(31) Saqlain, M. A.; Hussain, A.; Siddiq, M.; Leitao, A. A. RSC Adv. 2015, 5, 47066-47073.

(32) Bond, G. Gold Bull. 2009, 42, 337-342.

(33) Dimitratos, N.; Lopez-Sanchez, J. A.; Morgan, D.; Carley, A. F.; Tiruvalam, R.; Kiely, C. J.; Bethell, D.; Hutchings, G. J. Phys. Chem. Chem. Phys. 2009, 11, 5142-5143.

(34) Hou, W.; Dehm, N. A.; Scott, R. W. J. J. Catal. 2008, 253, 2227.

(35) Feng, J.; Ma, C.; Miedziak, P. J.; Edwards, J. K.; Brett, G. L.; Li, D.; Du, Y.; Morgan, D. J.; Hutchings, G. J. Dalton Trans. 2013, 42, 14498-14508.

(36) Wang, D.; Villa, A.; Spontoni, P.; Su, D. S.; Prati, L. Chem. - Eur. J. 2010, 16, 10007-10013.
(37) Pritchard, J.; Kesavan, L.; Piccinini, M.; He, Q.; Tiruvalam, R.; Dimitratos, N.; Lopez-Sanchez, J. A.; Carley, A. F.; Edwards, J. K.; Kiely, C.; Hutchings, G. J. Langmuir 2010, 26, 16568-16577.

(38) Chen, Y. T.; Lim, H. M.; Tang, Q. H.; Gao, Y. T.; Sun, T.; Yan, Q. Y.; Yang, Y. H. Appl. Catal., A 2010, 380, 55-65.

(39) Mars, P.; Scholten, J. J. F.; Zwietering, P. Adv. Catal. 1963, 14, $35-113$.

(40) Jacobs, G.; Patterson, P. M.; Graham, U. M.; Crawford, A. C.; Davis, B. H. Int. J. Hydrogen Energy 2005, 30, 1265-1276.

(41) Hirota, K.; Kuwata, K.; Nakai, Y. Bull. Chem. Soc. Jpn. 1958, 31, $861-864$.

(42) Ciftci, A.; Ligthart, D. A. J. M.; Pastorino, P.; Hensen, E. J. M. Appl. Catal., B 2013, 130-131, 325-335.

(43) Ojeda, M.; Iglesia, E. Angew. Chem., Int. Ed. 2009, 48, 48004803.

(44) Bollinger, M. A.; Vannice, M. A. Appl. Catal., B 1996, 8, 417.

(45) Wilson, A. R.; Sun, K.; Chi, M.; White, R. M.; LeBeau, J. M.; Lamb, H. H.; Wiley, B. J. J. Phys. Chem. C 2013, 117, 17557-17566.

(46) Marx, S.; Krumeich, F.; Baiker, A. J. Phys. Chem. C 2011, 115, $8195-8205$.

(47) Dellwig, T.; Rupprechter, G.; Unterhalt, H.; Freund, H. J. Phys. Rev. Lett. 2000, 85, 776-779.

(48) Hadjiivanov, K. I.; Vayssilov, G. N. Adv. Catal. 2002, 47, 307511.

(49) Ouyang, L.; Da, G.-j.; Tian, P.-f.; Chen, T.-y.; Liang, G.-d.; Xu, J.; Han, Y.-F. J. Catal. 2014, 311, 129-136.

(50) Redina, E. A.; Kirichenko, O. A.; Greish, A. A.; Kucherov, A. V.; Tkachenko, O. P.; Kapustin, G. I.; Mishin, I. V.; Kustov, L. M. Catal. Today 2015, 246, 216-231.

(51) Pilasombat, R.; Daly, H.; Goguet, A.; Breen, J. P.; Burch, R.; Hardacre, C.; Thompsett, D. Catal. Today 2012, 180, 131-138.

(52) Duan, K.; Liu, Z.; Li, J.; Yuan, L.; Hu, H.; Woo, S. I. Catal. Commun. 2014, 57, 19-22.

(53) Fujitani, T.; Nakamura, I. Angew. Chem., Int. Ed. 2011, 50, 10144-10147.

(54) Han, Y.-F.; Zhong, Z.; Ramesh, K.; Chen, F.; Chen, L.; White, T.; Tay, Q.; Yaakub, S. N.; Wang, Z. J. Phys. Chem. C 2007, 111, 8410-8413.

(55) Terribile, D.; Trovarelli, A.; de Leitenburg, C.; Primavera, A.; Dolcetti, G. Catal. Today 1999, 47, 133-140.

(56) Ricote, S.; Jacobs, G.; Milling, M.; Ji, Y. Y.; Patterson, P. M.; Davis, B. H. Appl. Catal., A 2006, 303, 35-47.

(57) Vidal, H.; Kaspar, J.; Pijolat, M.; Colon, G.; Bernal, S.; Cordon, A.; Perrichon, V.; Fally, F. Appl. Catal., B 2000, 27, 49-63.

(58) Jacobs, G.; Chenu, E.; Patterson, P. M.; Williams, L.; Sparks, D.; Thomas, G.; Davis, B. H. Appl. Catal., A 2004, 258, 203-214.

(59) Collins, S. E.; Cies, J. M.; del Rio, E.; Lopez-Haro, M.; Trasobares, S.; Calvino, J. J.; Pintado, J. M.; Bernal, S. J. Phys. Chem. C 2007, 111, 14371-14379.

(60) Acerbi, N.; Golunski, S.; Tsang, S. C.; Daly, H.; Hardacre, C.; Smith, R.; Collier, P. J. Phys. Chem. C 2012, 116, 13569-13583.

(61) Kugai, J.; Fox, E. B.; Song, C. Appl. Catal., A 2013, 456, 204214.

(62) Nascente, P. A. P.; Decastro, S. G. C.; Landers, R.; Kleiman, G. G. X. Phys. Rev. B: Condens. Matter Mater. Phys. 1991, 43, 4659-4666.

(63) Goodman, D. In Dekker Encyclopedia of Nanoscience and Nanotechnology, 2nd ed.; Contescu, C., Putyera, K., Eds.; CRC Press: Boca Raton, FL, USA, 2008; p 611.

(64) Bera, P.; Hegde, M. S. Catal. Lett. 2002, 79, 75-81.

(65) Casaletto, M. P.; Longo, A.; Martorana, A.; Prestianni, A.; Venezia, A. M. Surf. Interface Anal. 2006, 38 (4), 215.

(66) Venezia, A. M.; Pantaleo, G.; Longo, A.; Di Carlo, G.; Casaletto, M. P.; Liotta, F. L.; Deganello, G. J. Phys. Chem. B 2005, 109, 28212827.

(67) Boyd, D.; Golunski, S.; Hearne, G. R.; Magadzu, T.; Mallick, K.; Raphulu, M. C.; Venugopal, A.; Scurrell, M. S. R. Appl. Catal., A 2005, 292, 76-81.

(68) Fonseca, A. A.; Fisher, J. M.; Ozkaya, D.; Shannon, M. D.; Thompsett, D. Top. Catal. 2007, 44, 223-235. 
(69) Dalacu, D.; Klernberg-Sapieha, J. E.; Martinu, L. Surf. Sci. 2001, 472, 33-40.

(70) Willneff, E. A.; Braun, S.; Rosenthal, D.; Bluhm, H.; Havecker, M.; Kleimenov, E.; Knop-Gericke, A.; Schlogl, R.; Schroeder, S. L. M. J. Am. Chem. Soc. 2006, 128, 12052-12053.

(71) Rodriguez, P.; Plana, D.; Fermin, D. J.; Koper, M. T. M. J. Catal. 2014, 311, 182-189.

(72) Luo, K.; Kim, D. Y.; Goodman, D. W. J. Mol. Catal. A: Chem. 2001, 167, 191-198.

(73) Zhou, Y.; Peterson, E. W.; Zhou, J. Catal. Today 2015, 240, 201-205.

(74) Radnik, R.; Mohr, C.; Claus, P. Phys. Chem. Chem. Phys. 2003, 5, 172-177. 